\title{
Performance Study of SOFC-HAT Combined Cycle System with Variable Conditions
}

\author{
H.B. Zhao \\ College of Machinery and Transportation Engineering \\ China University of Petroleum Beijing \\ China
}

W. Yang

College of Machinery and Transportation Engineering China University of Petroleum Beijing

China

\author{
Q. Yang \\ College of Machinery and Transportation Engineering \\ China University of Petroleum Beijing \\ China \\ T. Jiang \\ College of Machinery and Transportation Engineering \\ China University of Petroleum Beijing \\ China
}

\begin{abstract}
In this paper, the detailed mathematical models are established for solid oxide fuel cell-humid air turbine (SOFC-HAT) combined cycle system, and the performances of the combined system are analyzed under variable conditions such as the fuel flow, pressure ratio and turbine initial temperature. At the typical working condition, the system

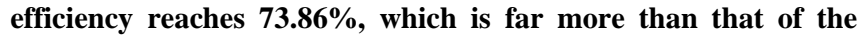
usual HAT cycle as well as the system combined with SOFC. The results disclosed in this paper can help to understand basic rules of the integrated system of SOFC and HAT so as to provide guidance for the design and operation of SOFC-HAT combined system.
\end{abstract}

Keywords-solid oxide fuel cells; humid air turbine; mathematical model; variable condition analysis; fuel reforming

\section{INTRODUCTION}

The performance of the combined system composed of reforming SOFC and gas turbine as well as thermal economics is analyzed in detail in the literature [1,2]. The internal and external reforming combined SOFC-GT system is adopted, and heat recovery of turbine exhaust is considered fully in the system. The research shows that the efficiency of this system can reach about $68 \%$ due to relatively better energy cascade utilization. Because natural gas can experience reforming reaction to generate hydrogen, natural gas can be used directly as fuel in SOFC. A large number of SOFC-GT researches adopt fuel internal reforming scheme [3]. However, the decomposition of methane in cells needs a process in the practical operation, if there are no external reforming units, that will cause hydrogen content excessively little so as to affect electrochemical reaction and result in the voltage too low. In addition, if the heat from replacing reaction is not enough to support reforming reaction, then the process will use the exhaust from combustion chamber to support necessary heat for the external reforming [4, 5]. Except for SOFC-GT systems, through the comparison of the SOFC-gas turbine combined cycle, SOFC-STIG and SOFC-HAT, it proves that the power efficiency of SOFC-HAT combined cycle is the highest in the same reaction conditions $[6,7]$.
However, in the existing literatures, the hydrogen is directly used as fuel in the SOFC-HAT combined system and internal low grade energy is not used fully; besides, the performances of the integration system have not been researched more thoroughly in variable conditions. The objective of this paper is to disclose the basic performance rules of the SOFC-HAT combined system, which adopts natural gas as the fuel and gives full consideration of waste heat using, and to investigate the effects of key parameters on the system performance.

\section{SYSTEM FLOW PROCESS}

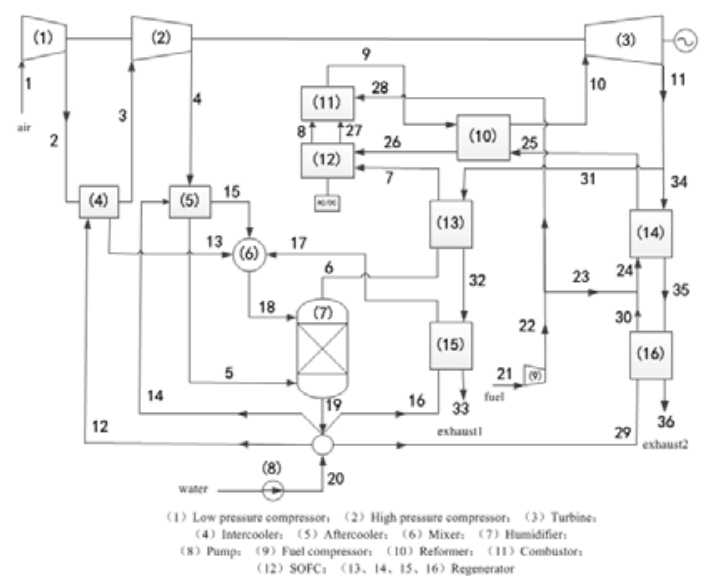

FIGURE I. THE LAYOUT OF THE SOFC-HAT HYBRID SYSTEM ANALYZED IN THIS PAPER.

As shown in Figure 1, firstly, air is compressed by low pressure compressor (1) and cooled in the intercooler (4), then its temperature and pressure further rise in the high pressure compressor (2) and its temperature drops through the after-cooler (5). Afterwards, it comes into humidifier (7) to increase humidity, in which the compressed air contacts with hot water coming from the top of the humidifier in countercurrent to exchange heat and quality, and a part of the hot water evaporates, at the same time, most of the cooled water flows out of the bottom of the humidifier to mix with 
supplemental water for recycling. After the humidified air leaves from the humidifier, it is preheated by the regenerator (13), and then it goes into SOFC to participate electrochemical reaction. After the natural gas is compressed by the compressor, a part of the fuel is preheated by the regenerator (14) and enters into reformer (10) to be reformed. Then it goes into SOFC to be further reformed and participates in the electrochemical reaction. Another part of the fuel and SOFC exhaust enter into the combustor (11) together to be burned to increase the temperature of them. Additionally, a part of the gas from the latter combustion chamber is utilized to provide heat energy for external reforming device. The exhaust of the turbine (3) is used to preheat fuel, air, steam, and circulating water of the combined cycle.

\section{IIIPERFORMANCE ANALYSIS OF SOFC-HAT COMBINED CYCLE SYSTEM}

\section{A. Performances in Specific Working Conditions}

According to the established performance mathematic calculation model of the combined system, the main property parameters of the SOFC-HAT combined cycle system is shown in Table 1 . The total power of the system is $3818 \mathrm{~kW}$, wherein, SOFC occupies $2305 \mathrm{~kW}$, accounting for about $60 \%$ of the total power output, and the gas turbine $1513 \mathrm{~kW}$, for about $40 \%$. The total efficiency reaches $73.86 \%$, which is much higher than that of the usual combined cycle systems.

TABLEI. MAIN PERFORMANCES OF SOFC-HAT SYSTEM IN PARTICULAR CONDITION

\begin{tabular}{ccc}
\hline Parameter & Unit & Number \\
\hline total power & 3818 & $\mathrm{~kW}$ \\
power of turbine & 2851.6 & $\mathrm{~kW}$ \\
power consumption of low pressure compressor & 492.2 & $\mathrm{~kW}$ \\
power consumption of high pressure compressor & 530.6 & $\mathrm{~kW}$ \\
power consumption of fuel compressor & 71.1 & $\mathrm{~kW}$ \\
power consumption of pump & 244.7 & $\mathrm{~kW}$ \\
current density of SOFC & 2709 & $\mathrm{~A} / \mathrm{m} 2$ \\
power of SOFC & 2305 & $\mathrm{~kW}$ \\
total power & 73.86 & $\%$ \\
\hline
\end{tabular}

B. Performance Analysis Under Variable Working Conditions

1) The effects of pressure ratio on performances of the system under different TIT: The moisture content of the humidifier changing with the pressure ratio is shown in Figure 2. The humidity increases with the pressure ratio increasing, because the added water increases with the pressure ratio increasing. At different TIT, the changing trend of the humidity with pressure ratio is basically consistent and becomes to slow down with pressure ratio increasing. Meanwhile, the humidity will increase with TIT increasing at the same pressure ratio. And the humidity is relatively more sensitive to the pressure ratio than the TIT.

In order to meet the requirement of the TIT, a certain amount of fuel needs to be supplemented into the combustion chamber. As shown in Figure 3, the added fuel quantity increases slowly with pressure ratio increasing in different TIT due mainly to the increment of the humidity.
The total power and efficiency of the system are shown in Figure 4 and Figure 5 respectively. The changing trend of the total efficiency is the same with that of the total power, exhibiting rising first and then falling down with pressure ratio increasing. For example, When the TIT is $1473 \mathrm{~K}$, the power of the whole system increases from $2904.2 \mathrm{~kW}$ to $3829.1 \mathrm{~kW}$ with pressure ratio increasing from 4 to 14 , at the same time, the fuel efficiency of the whole system increases from $57.57 \%$ to $74.06 \%$ and increases by $16.49 \%$; furthermore, when the pressure ratio increases from 14 to 20, the total power of the system drops from $3729.1 \mathrm{~kW}$ to $3632 \mathrm{~kW}$, and the efficiency drops from $74.06 \%$ to $69.99 \%$ and drops by $4.07 \%$. When the TIT changes from $1273 \mathrm{~K}$ to $1573 \mathrm{~K}$, the best pressure ratio for efficiency increases from 12 to 15, higher than that of general HAT cycle (8-12).

In addition, when the pressure ratio is fixed, the total power and efficiency of the system increase with TIT increasing. And the larger the pressure ratio is, the more obvious the influence of TIT change on the total power and efficiency of the system is.

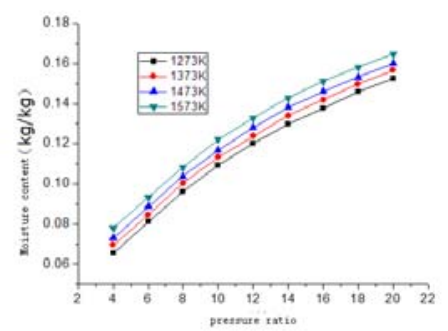

FIGURE II. EFFECT OF PRESSURE RATIO ON HUMIDITY.

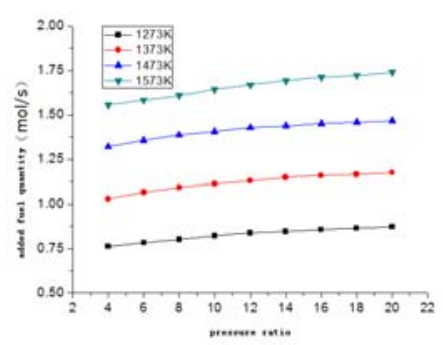

FIGURE III. EFFECT OF PRESSURE RATIO ON SUPPLEMENTARY FUEL

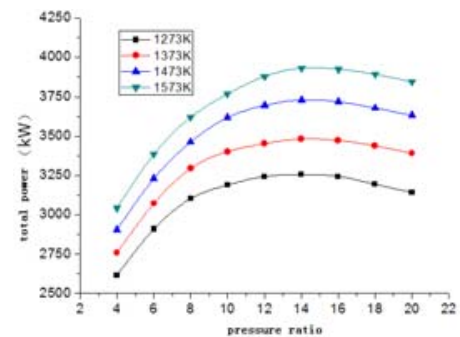

FIGURE IV.EFFECT OF PRESSURE RATIO ON TOTAL POWER 


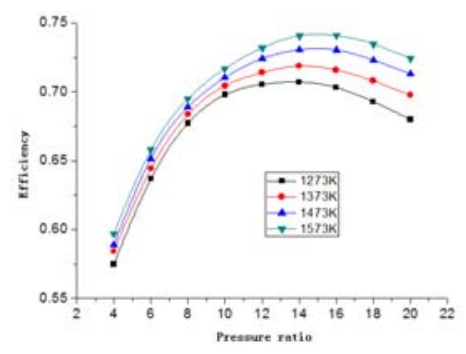

FIGURE V. EFFECT OF PRESSURE RATIO ON TOTAL EFFICIENCY

As is shown in Figure 6, the power of the SOFC increases with gas pressure ratio increasing and the increasing rate slows when the pressure ratio is larger than 8 . At the TIT of $1473 \mathrm{~K}$, when the pressure ratio increases from 4 to 8 , the power of SOFC increases from $2041 \mathrm{~kW}$ to $2227 \mathrm{~kW}$ and increases by $186 \mathrm{~kW}$; while from 8 to 20, the power of SOFC increases from $2227 \mathrm{~kW}$ to $2327 \mathrm{~kW}$ and increases by $100 \mathrm{~kW}$. Because operating pressure increases, the internal activation polarization of SOFC decreases, which causes the voltage of the battery to increase and the current density changes little, so that the power of SOFC increases. However, with the pressure ratio continuing to increase, the voltage growth of SOFC is not obvious, so the increasing speed of the power of SOFC slows. The power of SOFC increases with TIT rising at the same pressure ratio due to the rising of the inlet gas temperature of fuel cell cathode, which leads to the increment of the operating temperature of SOFC, and this reduces internal activation polarization of the battery and makes output power of SOFC increase.

Additionally, the net power output of the gas turbine exhibits the trend of rising first and then falling down with pressure ratio increasing. As shown in Figure 7, when the TIT is $1473 \mathrm{~K}$ and pressure ratio increases from 4 to 12 , the net work of gas turbine increases from $863 \mathrm{~kW}$ to $1439 \mathrm{~kW}$ and increases by $567 \mathrm{~kW}$; when pressure ratio continues to increase to 20 , the net work of gas turbine drops from $1439 \mathrm{~kW}$ to $1307 \mathrm{~kW}$ and drops by $132 \mathrm{~kW}$, this is mainly due to that when pressure ratio increases, work consumption of low-pressure compressor, high-pressure compressor, fuel compressor, and water pump increases.

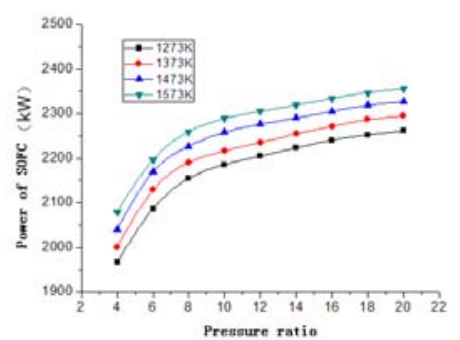

FIGURE VI. EFFECT OF PRESSURE RATIO ON SOFC POWER

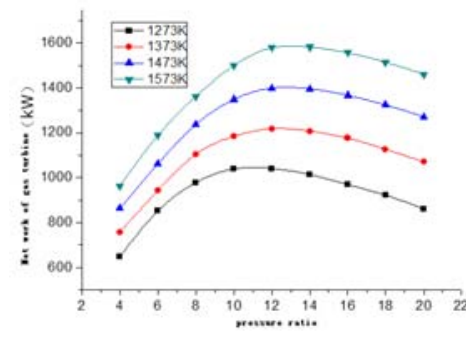

FIGURE VII

EFFECT OF PRESSURE RATIO ON NET TURBINE POWER

2) The effects of fuel flow rate on performances of the system under different TIT

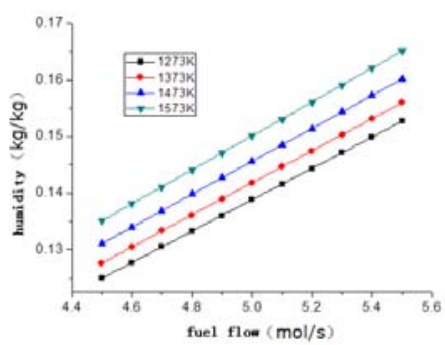

FIGURE VIII. $\quad$ EFFECT OF FUEL FLOW RATE ON HUMIDITY

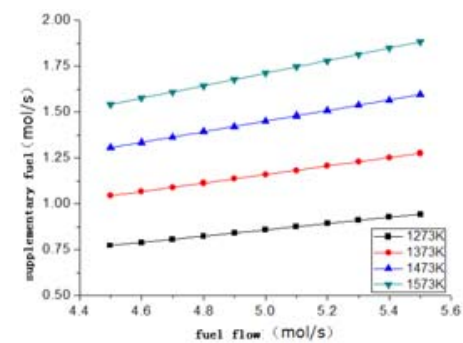

FIGURE IX. EFFECT OF FUEL FLOW RATE ON SUPPLEMENTARY FUEL

As shown in Figure 8, the humidity increases with fuel flow increasing and the changing tendency of relation curve of the humidity and fuel flow are basically consistent in different TIT. When the fuel flow is fixed, the humidity correspondingly increases with TIT rising. On the other hand, when the fuel flow is fixed, the humidity increases and the increasing speed becomes faster with TIT rising. The rising of TIT makes fuel supplement of combustion chamber increase, so the humidity increases.

When the TIT is fixed, the fuel supplement of combustion chamber also increases with fuel flow of SOFC increasing. As shown in Figure 9, when the TIT is $1473 \mathrm{~K}$, the fuel supplement of the system increases from $1.31 \mathrm{~mol} / \mathrm{s}$ to $1.6 \mathrm{~mol} / \mathrm{s}$ with fuel flow increasing from $4.5 \mathrm{~mol} / \mathrm{s}$ to $5.5 \mathrm{~mol} / \mathrm{s}$. Because when the fuel flow increases, the air flow and its humidity will increase correspondingly, the fuel supplement must increase in order to maintain the set value of the TIT.

As can be seen obviously from Figure 10 and Figure 11, the change trend of the total power and the total efficiency of the system is the same at different TIT, e.g., at the TIT of 
$1473 \mathrm{~K}$, when the fuel flow increases from $4.5 \mathrm{~mol} / \mathrm{s}$ to $5.2 \mathrm{~mol} / \mathrm{s}$, the total power of system increases from $3586 \mathrm{~kW}$ to $3834.4 \mathrm{~kW}$; and from $5.2 \mathrm{~mol} / \mathrm{s}$ to $5.4 \mathrm{~mol} / \mathrm{s}$, the total power declines to $3587 \mathrm{~kW}$. And the corresponding total efficiency of the system increases first from $70.89 \%$ to $73.93 \%$ and then drops to $68.09 \%$. The total power of the system quickly drops to $2949.2 \mathrm{~kW}$ and at the same time the total efficiency of the system quickly drops from $68.09 \%$ to $55.73 \%$ with the fuel flow continuing to increase to $5.5 \mathrm{~mol} / \mathrm{s}$.

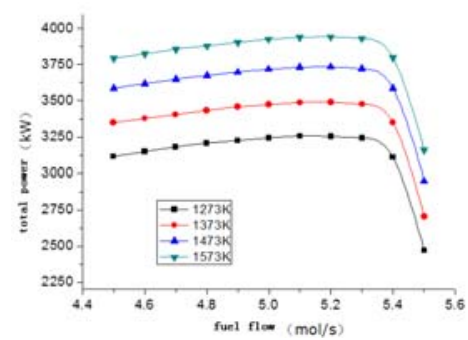

FIGURE X. EFFECT OF FUEL FLOW RATE ON TOTAL POWER

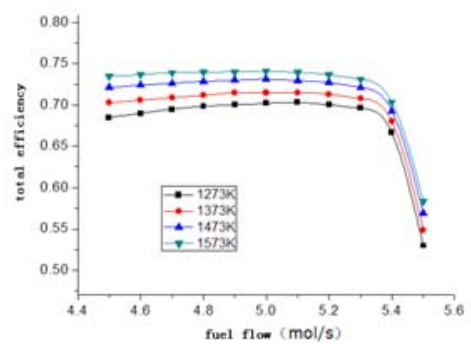

FIGURE XI. EFFECT OF FUEL FLOW RATE ON TOTAL EFFICIENCY

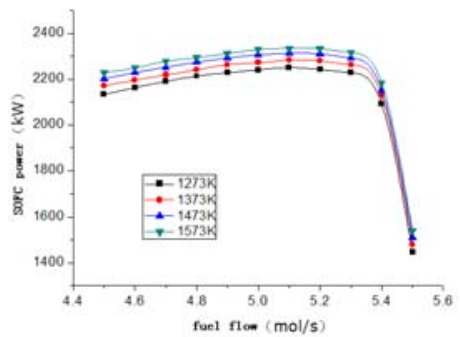

FIGURE XII.

EFFECT OF FUEL FLOW RATE ON SOFC POWER

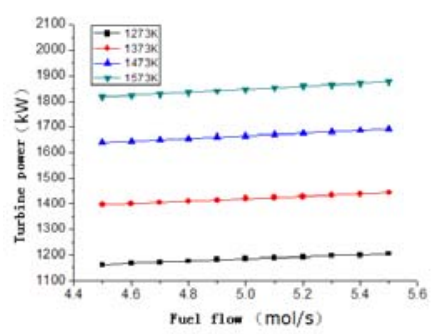

FIGURE XIII

EFFECT OF FUEL FLOW RATE ON NET TURBINE POWER

As shown in Figure 12, at the TIT of 1473K, when the fuel flow increases from $4.5 \mathrm{~mol} / \mathrm{s}$ to $5.1 \mathrm{~mol} / \mathrm{s}$, the power of SOFC increases from $2201 \mathrm{~kW}$ to $2313 \mathrm{~kW}$, and the power of SOFC quickly drops to $1509 \mathrm{~kW}$ with the fuel flow continuing to increase to $5.5 \mathrm{~mol} / \mathrm{s}$. The reason is mainly that the fuel flow increasing causes current density of fuel cells to increase, while the current density is close to restrictive current density of the battery, the polarization of the cell increases rapidly. Therefore, the power of SOFC first increases with fuel flow and then falls rapidly. Additionally, as shown in Figure 14, the net power of gas turbine increases due to the increase of the gas flow rate, for example, when the TIT is $1473 \mathrm{~K}$, the net power of gas turbine increases from $1385.6 \mathrm{~kW}$ to $1439.7 \mathrm{~kW}$ with fuel flow increasing from $4.5 \mathrm{~mol} / \mathrm{s}$ to $5.5 \mathrm{~mol} / \mathrm{s}$.

\section{IVSUMMARY}

In this paper, the detailed mathematical models are established based on the process of the SOFC-HAT combined system. The effects of key parameters on system performances are investigated. Following conclusions can be made based on the study:

(1) At the typical working conditions, the energy efficiency of the combined system attains $73.86 \%$.

(2) When the TIT is between $1273 \mathrm{~K}$ and $1573 \mathrm{~K}$, the best pressure ratio of the system efficiency changes from 12 to 15 which is less than that of ordinary SOFC-GT combined cycle and higher than that of general HAT cycle.

(3) With fuel flow increasing, the total power and total efficiency of the system increases first and then drops slightly, after over a certain value such as $5.4 \mathrm{~mol} / \mathrm{s}$, they declines quickly.

\section{ACKNOWLEDGMENTS}

The Project Supported by National Natural Science Founda tion of China: No. 51274224.

\section{REFERENCE}

[1] G. Vourliotakis, G. Skevis, M.A. Founti, Assessment of the reactor network approach for integrated modeling of an SOFC system, International Journal of Hydrogen Energy, Vol.36, Issue 10, pp. 6112-6122, 2011.

[2] F. Calise, M. Dentice d' Accadia, L. Vanoli , M.R. von Spakovsky, Single-level optimization of a hybrid SOFC-GT power plant, Journal of Power Sources, Vol.159, Issue 2, pp. 1169-1185, 2006.

[3] Chan S.H., Ho H.K., Tian Y., Modeling of simple hybrid solid oxide fuel cell and gas turbine power plant, Journal of Power Sources, Vol. 109, Issue 1, pp. 111-120, 2002.

[4] Georgopoulos N., Application of a decomposition strategy to the optimal synthesis/design and operation of a fuel cell based total energy system, Master's Thesis of Virginia Polytechnic Institute and State University, Blacksburg, 2001.

[5] Oyarzabal B., Application of a decomposition strategy to the optimal synthesis/design of a fuel cell sub-system, Master's Thesis of Virginia Polytechnic Institute and State University, Blacksburg, 2001.

[6] Prapan Kuchonthara, Sankar Bhattacharya, Atsushi Tsutsumi, Combinations of solid oxide fuel cell and several enhanced gas turbine cycles, Journal of Power Sources, Vol. 124, Issue 1, pp. 65-75, 2003.

[7] A.D. Rao, G.S. Samuelsen, A thermodynamic analysis of tubular SOFC based hybrid systems, ASME Paper, No. 2001-GT-0522, 2001. 